\title{
空調機停止後の発熱分布を考慮した室温上昇に関する研究 \\ EVALUATING ROOM TEMPERATURE RISE CONSIDERED DISTRIBUTION OF HEAT GENERATION AFTER A SHUTDOWN IN AIR-CONDITIONING UNITS
}

\author{
羽山広文*1, 木下 学*2, 倉㴊 隆*3, 絵内正道*4 \\ Hirofumi HAYAMA, Manabu KISHITA, Takashi KURABUCHI \\ and Masamichi ENAI
}

\begin{abstract}
The data processing equipment that is installed in computer rooms generates a large amount of heat, which is unevenly distributed in the room and may result in undesirably high local temperatures at places within the room. When the air-conditioning ceases to function due to power outages or system failure, this uneven distribution of temperatures in the room can become conspicuously large and result in stopping of the equipment operation or damage to the equipment. Our research involved the investigations listed below, with the objective of developing a convenient means of estimating the temperature distribution and the maximum temperature in a computer room where heat is generated unevenly after the air-conditioning system ceases to function.

(1) The temperature variation characteristic was evaluated from the results of full-scale model experiments.

(2) The factors that determine the standard deviation of the room temperature were identified and their effects were evaluated by means of multiple regression analysis.

(3) The factors that determine the standard deviation of the room temperature were used to indicate a method of easily estimating the maximum temperature within a room where the amount of heat generated is distributed unevenly.
\end{abstract}

Keyword: Air-conditioning, Room temparature, Reliability, Distribution of heat generation 空気調和, 室温, 信頼性, 発熱分布

1.はじめに

メディア情報を大量・高速に処理・伝達する情報システムは、今日 の高度情報社会の中で、重要な役割を果たしている。情報システムを 構築する機器は、高密度・大容量化のため発熱量が大きく、これらを 設置した機械室の発熱密度は一般オフイスと比較し著しく高くなって いる。情報機器は電子部品で構成されており、空気を冷媒として冷却 する方式の場合、機器周囲の室温を機器冷却用温度条件として規定す ることが多い。情報システムのダウンは、社会的な影響も大きなこと から、情報システムの適正な運用には、この機器冷却用温度条件を常 時要求される範囲に維持することが求められる。

情報機器は、機器ごとの発熱量にばらつきが大きいので、配置方法 によっては局所的に大きな発熱量の偏在をもたらすことがある。空調 機が正常に動作している場合、機器冷却用温度条件を満たすことは容 易である。しかし、停電や故障により空調設備が停止した場合、短時 間に室温が上昇するとともに、発熱量の偏在は、設置室内の温度分布 を助長させ、情報機器の停止ばかりではなく、熱破壊など甚大な被害 をもたらすことがある。このようなことから、情報機器の配置計画に は空調機停止時の室温分布を配慮することが重要となっている。
これまでに、高発熱機械室の空調気流方式に関して、実験や熱気流 解析を用いた研究がなされている。村上・加藤・田中ら 'は、OA機器 が設置された空間の空調気流方式について、排熱効率を用い給排気口 の適切な位置に関し評価している。また、村上・加藤2は、污染質の 室内濃度分布を低次のモーメントを用い表現し、換気効率の指標を提 案している。さらに、オフィスに関して、小島・渡辺ら ${ }^{3,4}$ /4、混合損 失の防止を主眼に室内空気温度分布の検討を行っている。しかし、こ れらは空調や換気が定常的に行われた環境下での検討であり、空調や 換気が停止した場合の室温分布の評価に関する報告は少ない。筆者ら 5)は高発熱機械室を対象に、空調機停止後の室温変化を考慮した空調 設備の信頼性について検討しているが、室温を 1 質点として扱い、機 器発熱量の偏在に伴う室温のばらつきは考慮されていないのが現状で ある。

そこで本研究では、室内の発熱量が偏在している機械室を対象に、 空調機停止後の室温分布や最高室温を簡便に予測する方法の提案を目 的に、以下の検討を行う。

1) 実大規模実験の結果から、室温のばらつきの特性を評価する。 2) 室温の標準偏差を決定する要因を抽出し、重回帰分析によりその影
${ }^{* 1}$ 北海道大学大学院工学研究科 助教授 · 博士 (工学)

*2 NTTファシリティーズ研究開発部 修士(工学)

*3 東京理科大学工学部建築学科 助教授・博士 (工学)

*4 北海道大学大学院工学研究科 教授. 工博
Assoc. Prof., Graduate School of Engineering, Hokkaido University, Dr. Eng Research and Development Dept., NTT Facilities, M. Eng.

Assoc. Prof., Dept. of Architecture Faculty of Engineering, Science University of Tokyo, Dr. Eng.

Prof., Graduate School of Engineering, Hokkaido University, Dr. Eng. 

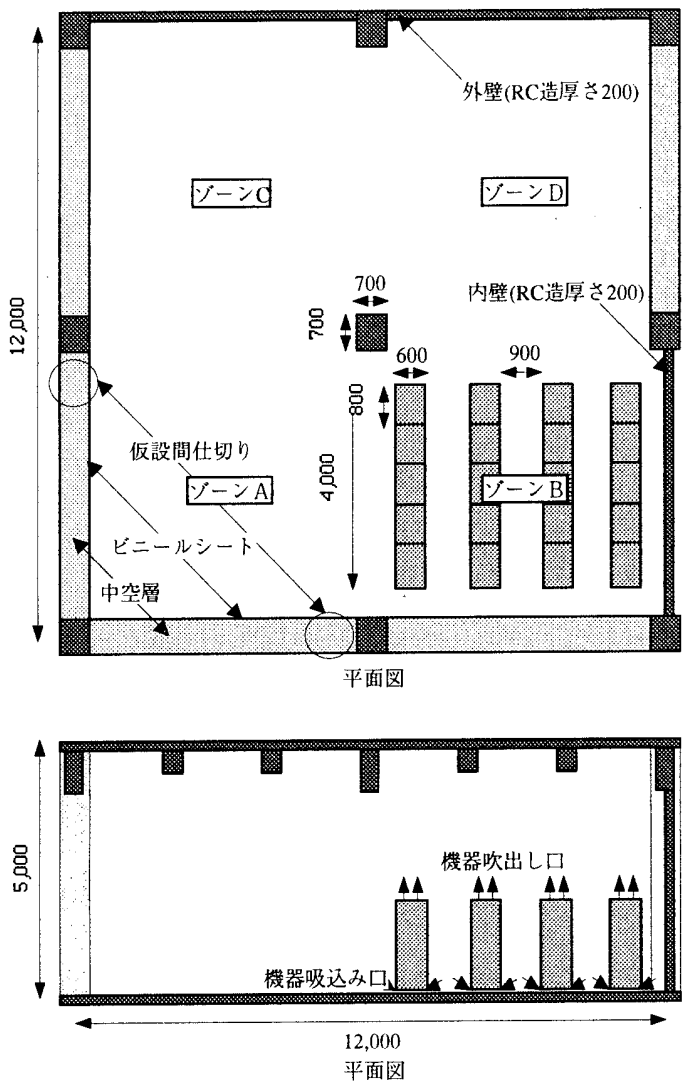

図 1 実験室の概要

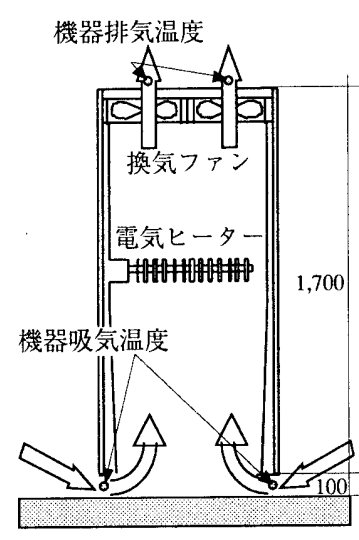

図 2 模擬発熱体の概要
表 1 実験室・発熱体の概要

\begin{tabular}{|c|c|c|}
\hline 実験 等 & 㮌積 & $(12$ \\
\hline 施設 & 天井高 & \\
\hline 模擬 & 寸法 & $\mathrm{H1} .8 \times \mathrm{W} 0.8 \times \mathrm{D} 0.6[\mathrm{~m}]$ \\
\hline 装置 & 換気量 & \\
\hline & 發 & 最大 $5[\mathrm{~kW} /$ 台] \\
\hline
\end{tabular}

\section{表 2 測定項目と測定点}

\begin{tabular}{|c|c|c|}
\hline \multirow{2}{*}{$\begin{array}{l}\text { 測定項目 } \\
\text { 室内空間 }\end{array}$} & 仕㥞 & 点数 \\
\hline & $\begin{array}{l}\text { 平面36点 } \times \text { 高さ4点 } \\
\mathrm{FL}+0.5,1.5,2.5,3.5[\mathrm{~m}]\end{array}$ & 144 \\
\hline 壁面（内外） & $\begin{array}{l}8 \text { カ所 } \times \text { 高さ4点 } \\
\text { FL+0.5.1.5.2.5,3.5[m] }\end{array}$ & 32 \\
\hline 装置吸排気 & 吸排気 2 点 $\times 20$ 台 & 40 \\
\hline 隣室 & 各1点×4力所 & 4 \\
\hline 天井面 & 各ゾーン1点 $\times 4$ ゾーン & 4 \\
\hline 床面 & 各ゾーン1点 $\times 4$ ゾーン & 4 \\
\hline 外気 & & 1 \\
\hline
\end{tabular}

響を評価する。

3) 室温の標準偏差を決定する要因を用い、発熱量が偏在した室内の最 高温度を簡易に予測する方法を示し、その予測精度を評価する。

\section{2. 室内温度上昇の実験}

\section{1 実験設備}

空調機停止時の室温分布の特性を把握するため、実大規模の実験を 行った。実験には RC 造 2 階建て建物の 2 階機械室の一部を使用した （図 1)。実験スペースの床面積は $144 \mathrm{~m}^{2} 、$ 階高 $5 \mathrm{~m}$ である。実験スペー スの壁面の内訳は、1 面が外壁 ( $\mathrm{RC}$ 造)、0.5 面が内壁 ( $\mathrm{RC}$ 造)、他の 2.5 面が仮設間仕切りとなっている。この仮設間仕切りで周囲のス ペースと区画した。仮設間仕切りを隔てた隣室には、運用中の情報シ ステムが設置されており、空調システムの運転により、その室温は約
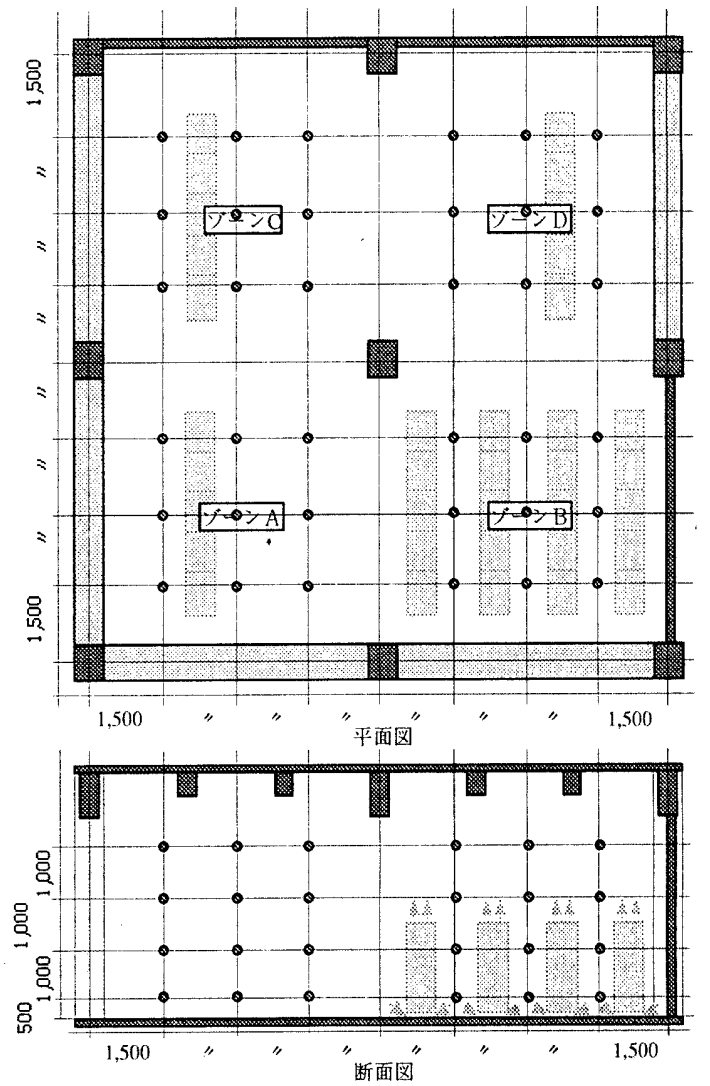

図 3 温度の測定位置

$25^{\circ} \mathrm{C}$ に維持されている。

室内には表1に示す模擬発熱機器を20台設置した。模擬発熱機器は 実際の情報機器と同様に機器上部に排気用ファン $\left(1,400 \mathrm{~m}^{3} / \mathrm{h}\right)$ を設 け、機器の底面より室内の空気を吸込み、機器内に設置された電気 ヒーターを冷却する強制空冷タイプとなっている(図2)。各模擬発熱

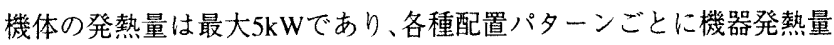
を変化させることができる。

温度の測定は、表 2 に示す要領で行った。温度センサーを図 3 に示 す位置に設置した。全測定項目について、実験開始後 1 分ごとの值を データロガーに記録した。

\section{2 実験方法}

実験スペースの床面積 $36 \mathrm{~m}^{2}$ を1ゾーンとし、A〜Dの各ゾーンで の機器配置および発熱量を変化させた。図4に示す機器配置および各 機器の発熱量の計 12 パターンの実験を行った。各点の温度は、実験開 始後 5 時間 30 分 6 時間記録した。

\section{2 . 3 垂直および平面の室温分布}

各実験の中から典型的な配置パターンを選択し、実験NO.1-2、1-3、 2-3、3-4の4ケースについて室温分布の実験結果を分析した。図5に 実験開始後 5 時間 30 分後における、室温の垂直および水平温度分布を 等温線図で示す。

実験NO.1-2では、4つのゾーンの発熱体を分散して設置し、各機器 の発熱量を均一に与えた。西面の壁面近くでの温度上昇が見られるほ か、水平面の温度のばらつきは少ない。また、垂直温度分布の結果か らも概ね均一な室内温度分布となっていることがわかる。

実験NO.1-3では、4つのゾーンの発熱体を分散して設置し、各ゾー ンの発熱量に差を設けた。垂直温度分布の結果から、発熱量の大きな ゾーンでは上下方向の温度のばらつきがやや顕著になっているもの 
の、水平温度のばらつきは比較的少ない。また、ゾーン Bに設置した 発熱体は発熱量に差をつけているにも関わらず、水平方向の室温のば らつきに顕著な差が見られなかった。

実験NO.2-3では、ゾーンA、Bのみに発熱体を設置した。垂直およ び水平面の温度分布をみると、発熱体が設置されている領域で温度が 高くなっており、発熱体が設置されていない領域との間で温度差が生 じている。

実験 NO.3-4では、発熱体をゾーン B のみに設置した。局所的に大 きな発熱量が集中しているため、垂直方向および水平方向の温度のば らつきは大きくなっている。

発熱体が室内に分散されて設置されている場合、発熱体に付設され た換気ファンにより、熱の拡散が促進されるが、発熱体が局所的に集 中して設置されるにともない、換気ファンによる熱の拡散も十分に行 われなくなり、結果的に室温のばらつきが顕著になるといえる。

\section{4 室温の頻度分布}

実験NO.1-2、1-3、2-3、3-4 から得られた室温の頻度分布を図6に示 す。なお、このデー夕は発熱開始後 5 時間 30 分における 144 点の值を 用いている。これらの結果から、発熱量の等しい機器を分散して設置 したNO.1-2 と比較し、発熱量が局所に偏在する設置パターンでは、高 温側の裾野は拡大し、モードは平均值よりやや低い値となる。しか し、各実験における室温の頻度分布から、温度分布の歪度の值も比較 的小さく、正規分布と見なすことができる。

\section{5 室温の平均温度上昇}

総発熱量の等しい実験 NO.1-2、1-3、2-3、3-4について、実験開始 後の経過時間と平均室温上昇の関係を図 7 に示す。平均室温は、実験 開始後約30分間で急激に上昇し、その後徐々に上昇する。実験開始後 5 時間を経過しても平均室温は上昇を続け、定常には至っていない。 総発熱量が等しい各実験での平均室温上昇は、発熱量が偏在している
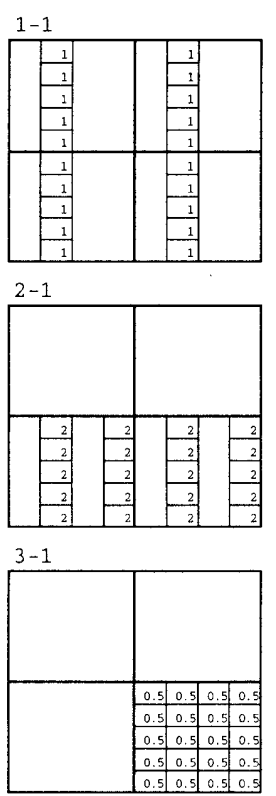
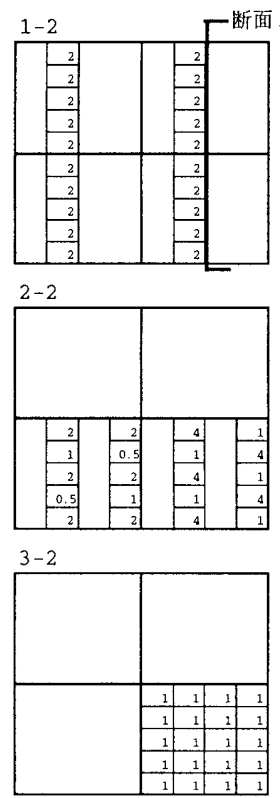

図4 発熱体の発熱パターン（単位：kW）
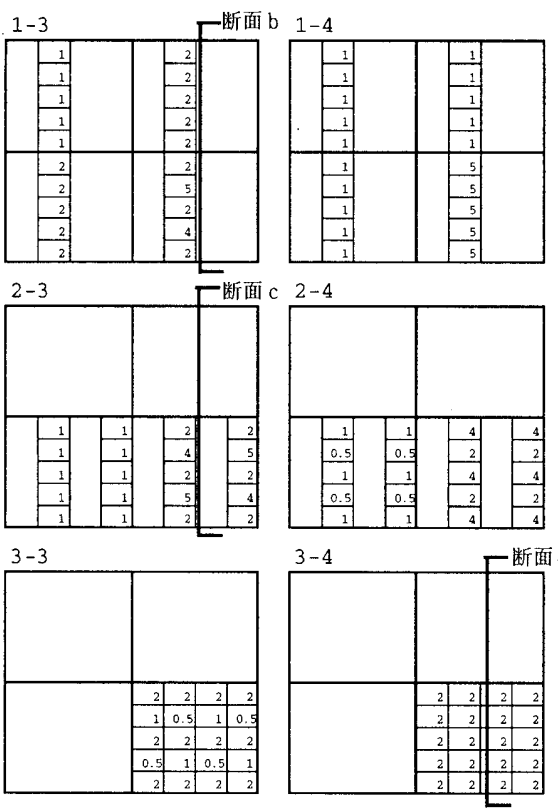
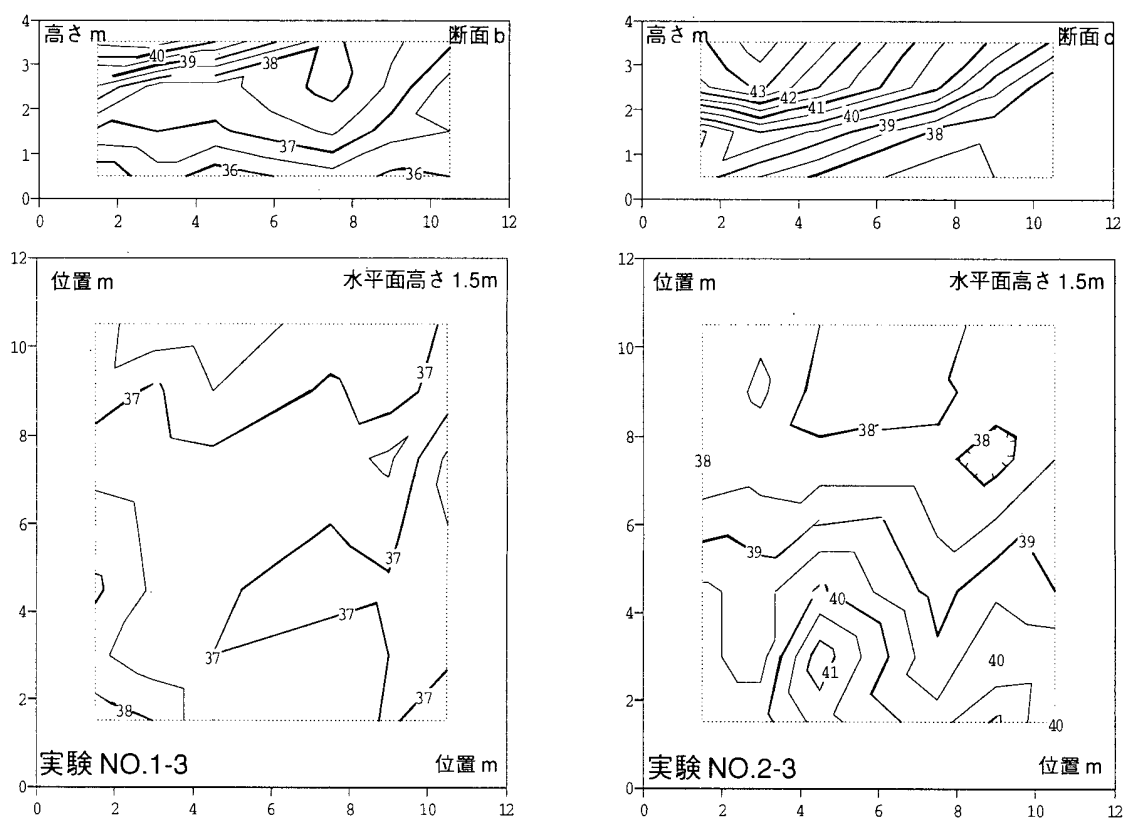
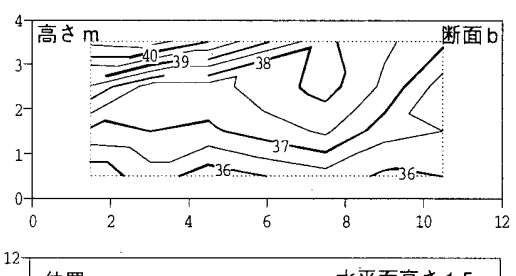

02

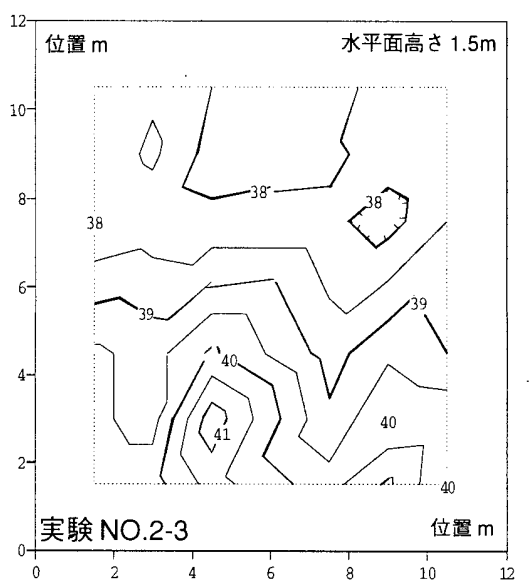

図 5 室内の垂直および水平温度分布
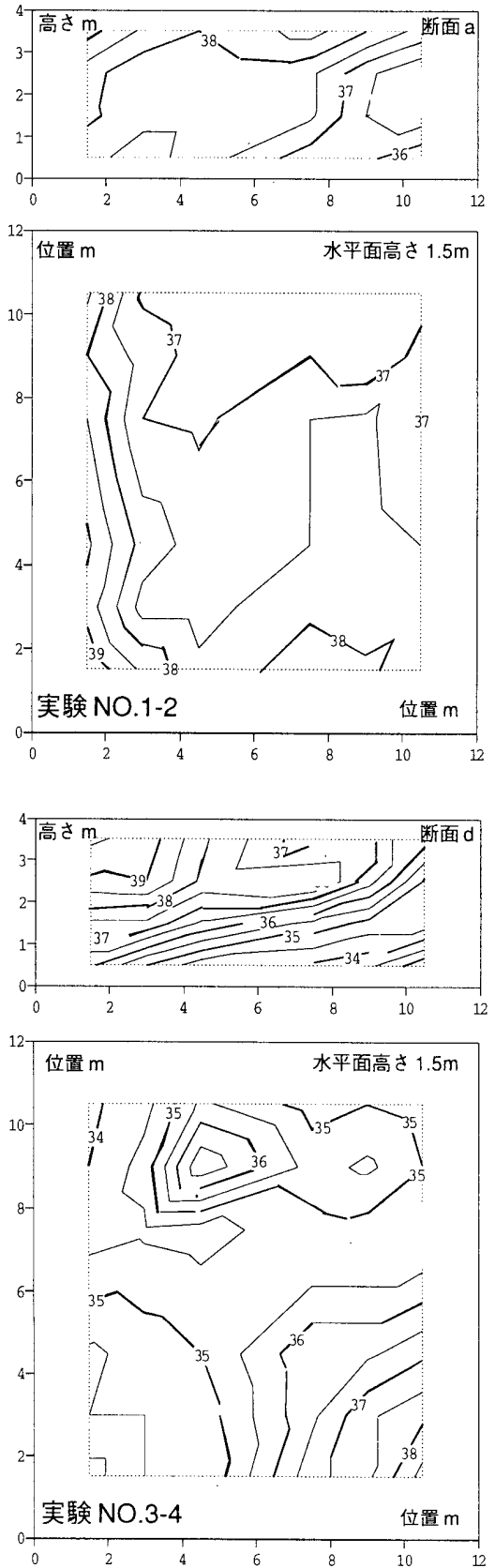
にも関わらず、概ね同一の傾向を示す。各実験ごとに多少の違いが生 ずる原因は、各実験が異なる日時に実施されたため、外気条件の違い などが考えられる。しかし、その影響は相対的に小さく、各実験での 平均室温上昇は概ね同一と見なすことができる。

\section{6 室温の標準偏差}

実験開始後の経過時間と室温の標準偏差の関係を図8に示す。各実 験パターンで共通して見られることは、実験開始後数分間に標準偏差 が急激に上昇し、その後ゆっくりとした変化を示すことである。発熱 体が局所的に偏在している実験NO.2-3、3-4では、実験開始後約 1 時 間程度で概ね定常となっているのに対し、発熱体が室内に分散設置さ れた実験NO.1-2、1-3では、実験開始後短時間で定常になっている。こ れは、発熱体が室内に分散設置された場合、発熱体に付設された換気 ファンにより熱の搪散が十分に行われ、発熱体が局所的に偏在される のに伴い、熱の拡散が滞るためと考えられる。

\section{7 室内の最高温度の予測}

今回、検討の対象としている通信用建物の場合、通信機器は室内の 1.8〜2.7[m]程度の範囲に設置されることが多い。しかし、室内には通 信用ケーブル、これに付属する各種機器が各所に設置されている。こ のため、室内に設置されている機器の動作を保証するには、室内の最 高温度を規定温度以下に保つことが求められる。

一般的に正規分布になっているデータは、平均值 $\mathrm{T}_{\mathrm{ave}}$ とその標準偏 差 $\sigma$ とすると、最高値は次式で表され、 $\mathrm{T}_{\mathrm{ave}} \pm 3 \sigma$ ，の範囲に $99.7 \%$ の データが含まれる。

$$
T_{\text {max }}=T_{\text {ave }}+3 \sigma_{t}
$$

今回実験を行った中から、実験NO.1-2、1-3、2-3、3-4の4つについ て、測定されたデータから求めた平均室温 $\mathrm{T}_{\text {ave }}$ 、室温の標準偏差 $\sigma$ ，を 用い(1)式から最大値を求めた。測定された最大値と計算値の関係を図
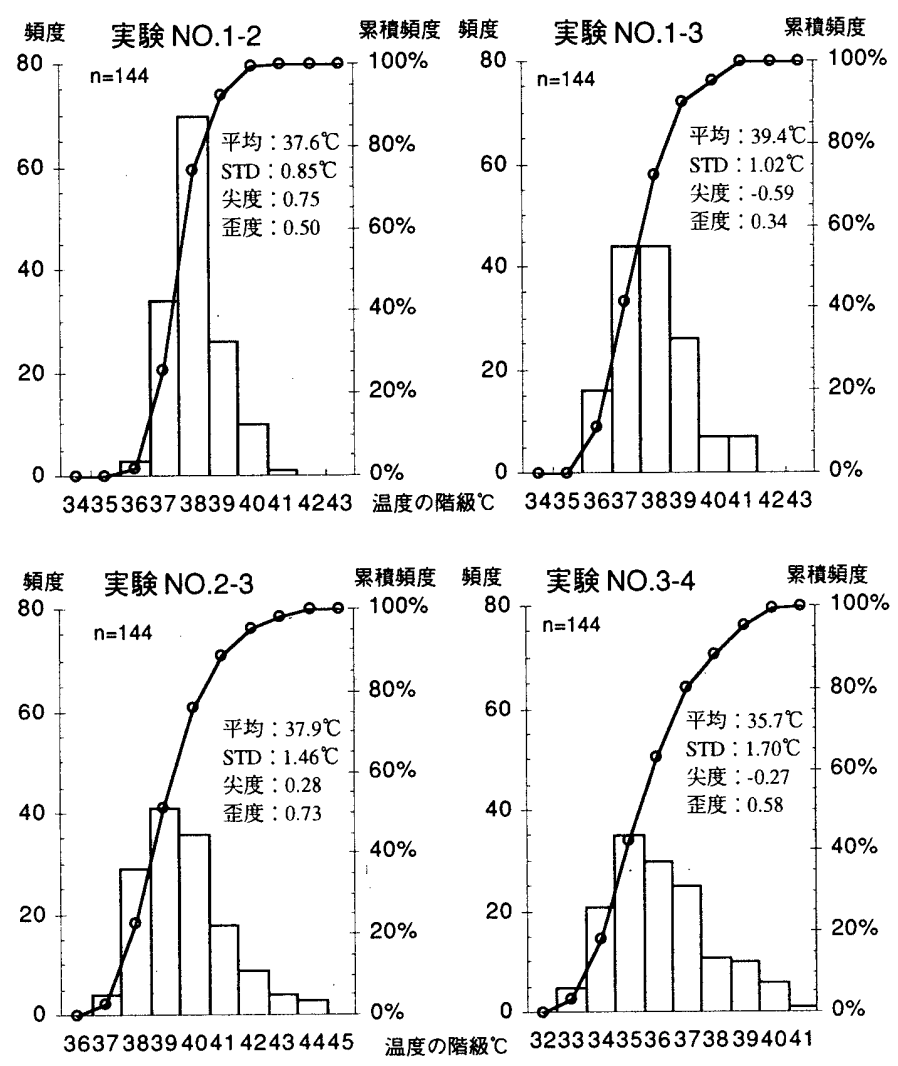

図 6 室内温度の頻度分布
9に示す。その結果、計算値と測定値は非常に良く一致しており、室 温の平均値とその標準偏差を用い室温の最大値を概ね良好な精度で予 測できることが確認できた。

本論文の実験結果から以下のことがいえる。

1) 室温分布は正規分布と見なせる。

2) 平均室温上昇は発熱量の偏在に関わらず同一の傾向と見なせる。

3) 室温の標準偏差は短時間で定常に達する。

4) 室温の最大值を(1)式から推定することができる。

平均室温は、室内の発熱量、建物構成材料の熱特性、外気条件など が既知であれば、室温を1質点とし計算により容易に求めることがで きる。その一方で、室温の標準偏差は発熱体の設置状態、発熱量の偏 在の程度により大きく異なることが予想される。そこで、本論文では 発熱体の設置状態、発熱量の偏在と室温の標準偏差の関係を明確に

し、室内最高温度の予測を試みた。

3. 室温のばらつきの要因分析

3. 1 室温のばらつきの要因

各要因と室温のばらつきの関係を評価し、室温のばらつきを説明す

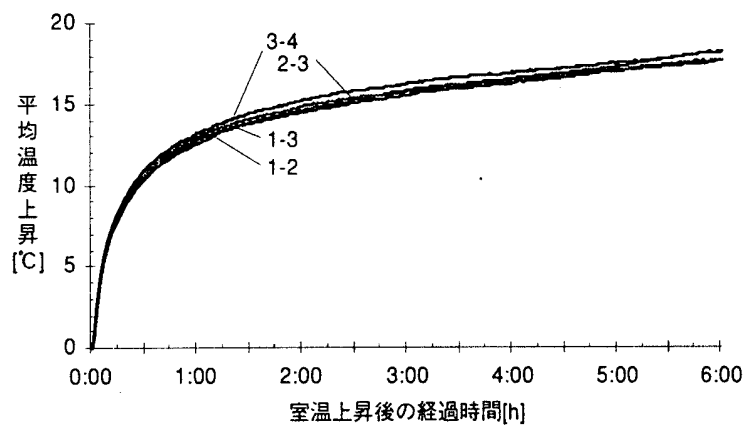

図 7 経過時間と平均室温上昇

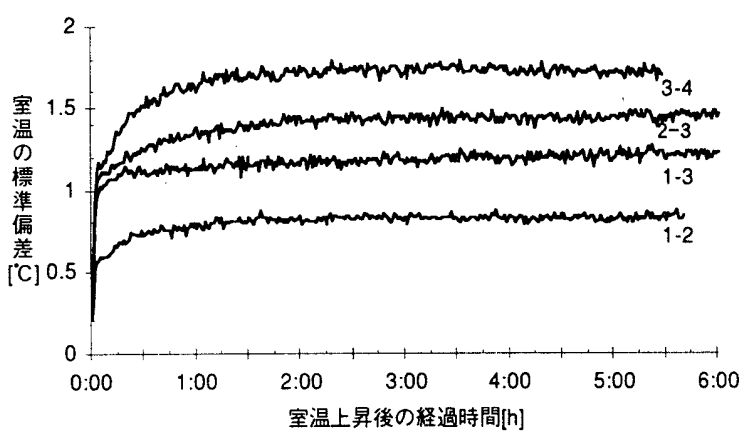

図 8 経過時間と室温の標準偏差

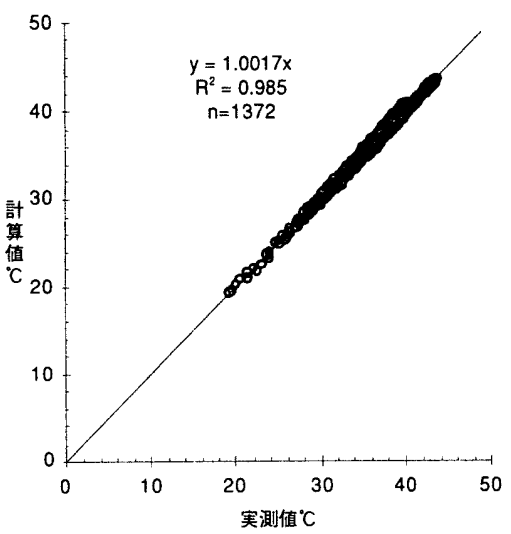

図 9 室内最高温度上昇の測定值と計算値の比較 
るのに有効な要因について検討するため、室温のばらつきと関連の深 い要因として、以下の項目を設定した。

\section{(1) 発熱量 (平均発熱密度)}

機器の発熱量を表す指標として、床面積 $\mathrm{A}_{\mathrm{a}}\left[\mathrm{m}^{2}\right]$ 、機器の発熱量 $\mathrm{H}_{\mathrm{m}}$ $[\mathrm{W}]$ を用いた室平均の発熱密度 $h_{\mathrm{a}}\left[\mathrm{W} / \mathrm{m}^{2}\right]$ があり、これを要因として設 定する。この指標は、平均室温を推定する際にも用いられる。

$$
h_{a}=\frac{H_{m}}{A_{a}}
$$

\section{（2）機器発熱量の偏在１（室中心と発熱の重心の距離）}

室温のばらつきが発熱の偏在によるものと考えると、室内における 発熱体の位置とその量を評価する必要がある。発熱している機器が平 面的に分布している場合、そこで発生する熱量の拡散は、発熱体が室 中央の位置に設置されている方が、容易で、室温のばらつきは小さく なると考えられる。そこで、室中央と発熱の重心の距離を設定する。 発熱体の位置 $\left(\mathrm{x}_{\mathrm{i}}, \mathrm{y}_{\mathrm{i}}\right)$ 、発熱量 $\mathrm{H}_{\mathrm{i}}$ 、室中央の位置 $\left(\mathrm{x}_{0}, \mathrm{y}_{0}\right)$ 、総発熱量 $\mathrm{H}_{\mathrm{m}}$ 、発 熱の重心の位置 $(\mathrm{x}, \mathrm{y})$ とすると、室中心と発熱の重心の距離 $\mathrm{L}_{\mathrm{h}}$ は、次式 となる。

$$
\begin{aligned}
& L_{h}=\sqrt{\left(x-x_{0}\right)^{2}+\left(y-y_{0}\right)^{2}} \\
& \text { ただし、 } x=\frac{\sum\left(x_{i} H_{i}\right)}{H_{m}} \quad y=\frac{\sum\left(y_{i} H_{i}\right)}{H_{m}}
\end{aligned}
$$

\section{(3) 機器発熱量の偏在 2 （マハラビノスの汎距離）}

発熱している機器が平面的に分布している場合、室中央と発熱の重 心までの距離が同じであっても、発熱体の分布のばらつきが大きな方 が、室温のばらつきは小さくなると考えられる。これを勘案して、発 熱の偏在および発熱の分散の双方を表す指標として、マハラビノスの 沉距離を設定する。マハラビノスの沉距離は、同じユークリッド距離 でもそのばらつきが大きなほど小さな值となる性質があり、ばらつき のある現象を評価する上で有効な指標といえるの。

2 点間の距離を $\mathrm{L} 、 2$ 点間の距離の平均值を $\bar{L} 、 そ の$ 標準偏差を $\sigma$ とすると、1 次元 (1 変数) におけるマハラビノスの沉距離Dの二乗 は基準値を二乗した值で表され、次式で示される。

$$
D^{2}=\left(\frac{L-\bar{L}}{\sigma}\right)^{2}
$$

二次元の場合、各機器の位置と室中心の位置との差を $\left[\mathrm{L}_{\mathrm{x}} \mathrm{L}_{\mathrm{y}}\right]$ と表し、 分散・共分散行列[V]の逆行列を[V] ${ }^{-1}$ とすると、マハラビノスの沉距 離 D は次式で求められる6)。

\begin{tabular}{|c|c|c|c|c|c|c|}
\hline $\begin{array}{l}\text { 実験 } \\
\text { NO. }\end{array}$ & $\begin{array}{l}\text { 発熱量 } \\
{[\mathrm{kW}]}\end{array}$ & $\begin{array}{l}\text { 平均発熱密 } \\
\text { 度 } h_{\mathrm{a}}[\mathrm{W} / \mathrm{m} 2]\end{array}$ & $\begin{array}{c}\text { 室中心重 } \\
\text { 心距離 } \\
\text { L. }[\mathrm{m}] \\
\end{array}$ & $\begin{array}{c}\text { マハラビノスの汎 } \\
\text { 距離D[m] }\end{array}$ & $\begin{array}{c}\text { 平均室温- } \\
\text { 外気温度 } \\
\triangle \mathrm{T}^{\circ} \mathrm{Cl} \\
\end{array}$ & $\begin{array}{c}\text { 至温の標 } \\
\text { 準偏差 } \\
\sigma .{ }^{\circ} \mathrm{Cl} \\
\end{array}$ \\
\hline $1-1$ & 20 & 0.139 & 0.00 & 0.00 & 8.9 & 0.54 \\
\hline $1-2$ & 40 & 0.278 & 0.00 & 0.00 & 16.9 & 0.85 \\
\hline $1-3$ & 40 & 0.278 & 1.19 & 0.36 & 17.1 & 1.02 \\
\hline $1-4$ & 40 & 0.278 & 2.40 & 0.69 & 17.7 & 1.22 \\
\hline $2-1$ & 40 & 0.278 & 3.00 & 2.65 & 17.7 & 1.46 \\
\hline $2-2$ & 40 & 0.278 & 3.08 & 2.58 & 18.3 & 1.44 \\
\hline $2-3$ & 40 & 0.278 & 3.35 & 2.89 & 18.7 & 1.42 \\
\hline $2-4$ & 40 & 0.278 & 3.50 & 2.60 & 18.2 & 1.46 \\
\hline $3-1$ & 10 & 0.069 & 4.25 & 3.21 & 5.0 & 0.81 \\
\hline $3-2$ & 20 & 0.139 & 4.25 & 3.21 & 9.2 & 1.09 \\
\hline $3-3$ & 30 & 0.208 & 4.25 & 3.01 & 14.6 & 1.47 \\
\hline $3-4$ & 40 & 0.278 & 4.26 & 3.20 & 14.6 & 1.70 \\
\hline
\end{tabular}

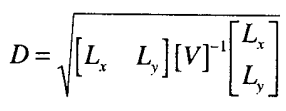

表 3 各実験パターンと各項目の值

\section{（4）室内外温度差}

室内で発生する熱量は建物の壁体を貫流し室外へ放熱されるととも に、間仕切り壁を貫流し隣室へ放熱される。本論文の実験では各実験 が異なる日時で行われているため、これを補正する必要がる。そこ で、実験中における平均室温と平均外気温度の差として平均室内外温 度差 $\Delta \mathrm{T}$ を設定する。室内の平均発熱密度が高くなることにより、室 内外の温度差も大きくなることから、この指標は平均発熱密度、外気 条件、建物の熱性能などを評価するものといえる。なお、建物が異な る場合でも沉用的に利用できる関係を導くには、熱性能の異なる建物 での実験が必要となる。しかし、本論文では通信用建物として多く用 いられている $\mathrm{RC}$ 造の建物での春験に基づいている。

$$
\Delta T=T_{r, a v e}-T_{o, a v e}
$$

\section{2 室温の標準偏差の重回帰分析}

室温のばらつきの要因と考えられる4項目 (説明変数) と室温の標 準偏差 (目的变数)の関係を明確にするため、各項目の相関行列を求 めた (表 4)。その結果、各説明変数と室温の標準偏差の相関は 0.602 〜0.649でほほ同程度の值であった。一方、「平均発熱密度」と「平均 室温一外気温度」「室中心と発熱の重心の距離」と「マハラビノスの

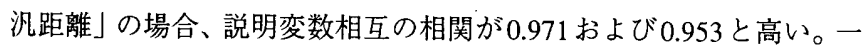
般的に説明変数の採否の判定には目的変数との相関係数が小さな項 目、また、説明変数相互の相関が大きな項目を外すことが良いとされ

\begin{tabular}{|c|c|c|c|c|c|}
\hline & $\begin{array}{c}\text { 平均登熱 } \\
\text { 密度 } \\
h_{a}\left[\mathrm{~W} / \mathrm{m}^{2}\right] \\
\end{array}$ & $\begin{array}{c}\text { 室中心-重 } \\
\text { 心距離 } \\
\mathrm{L}_{\mathrm{h}}[\mathrm{m}] \\
\end{array}$ & 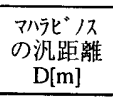 & $\begin{array}{c}\text { 平均室温- } \\
\text { 外気温 } \\
\triangle \mathrm{T}\left[{ }^{\circ} \mathrm{C}\right]\end{array}$ & $\begin{array}{c}\text { 室温の標 } \\
\text { 準偏 } \\
\left.\sigma_{[1}{ }^{\circ} \mathrm{C}\right] \\
\end{array}$ \\
\hline 平均発熱密度 $h_{a}\left[\mathrm{~W} / \mathrm{m}^{2}\right]$ & 1 & & & & \\
\hline 室中心-重心距離 $\mathrm{L}_{\mathrm{h}}[\mathrm{m}]$ & -0.168 & 1 & & & \\
\hline マルラビ ルスの沉距離 $\mathrm{D}[\mathrm{m}]$ & -0.176 & 0.953 & 1 & & \\
\hline 平均室温-外気温度 $\Delta \mathrm{T}\left[{ }^{\circ} \mathrm{C}\right]$ & 0.971 & -0.139 & -0.142 & 1 & \\
\hline 室温の標準偏差 $\left.\sigma{ }^{1}{ }^{\circ} \mathrm{C}\right]$ & 0.610 & 0.649 & 0.631 & 0.602 & 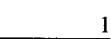 \\
\hline
\end{tabular}
ているの。ここでは算出が容易なこと、発熱の偏在の程度を表現でき

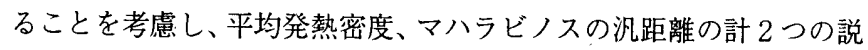

\begin{tabular}{|c|c|c|c|c|}
\hline & 偏回帰係数 & 標準誤差 & $\mathrm{t}$-值 & P-值 \\
\hline 切片 & 0 & - & - & - \\
\hline 平均発熱密度 $h_{\mathrm{a}}\left[\mathrm{W} / \mathrm{m}^{2}\right]$ & 3.4740 & $1.762 \mathrm{E}-01$ & 19.72 & $2.464 \mathrm{E}-09$ \\
\hline マイラビルスの汎距離D[m] & 0.1978 & $1.775 \mathrm{E}-02$ & 11.14 & $5.865 \mathrm{E}-07$ \\
\hline
\end{tabular}
明変数を採用することとする。

上記の $2 つ の$ 説明変数を用い、室温の標準偏差を目的変数として重

表 4 相関行列

表 5 重相関分析の結果

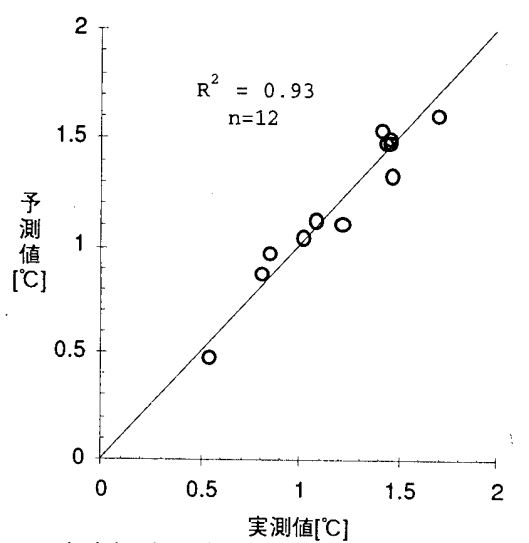

図 10 室内温度標準偏差の実測値と予測値の比較 

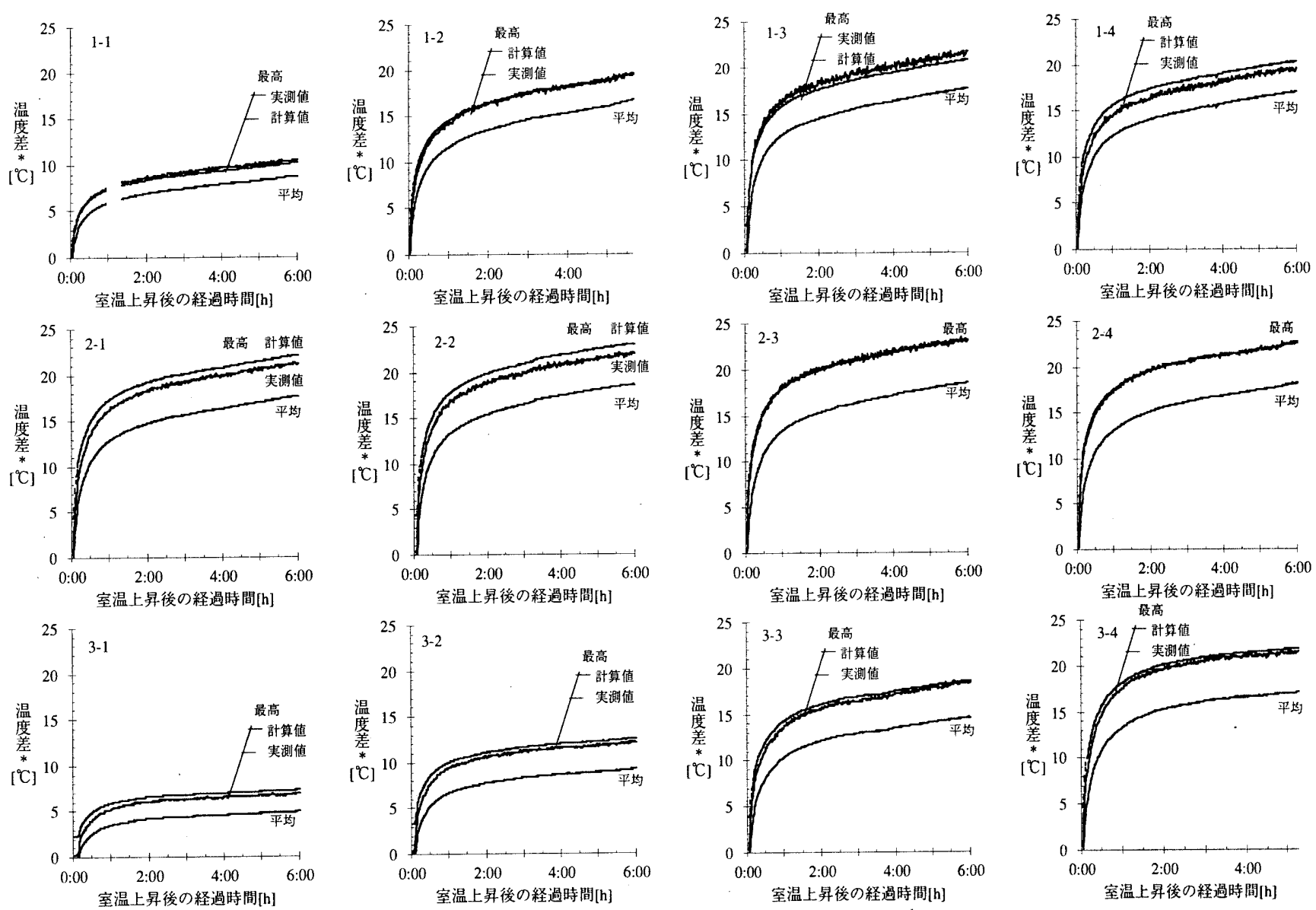

図 11 室内温度上昇の実測値と計算值の比較

相関分析を行った。各目的変数に対する偏相関係数、標準誤差、 $\mathrm{t}$ 值、 $\mathrm{P}$ 值を表 5 に示す。一般に $\mathrm{t}$ 值（偏回帰係数/標準誤差）は説明変数の 検定に用いられ、 $t \geq \sqrt{2}$ の場合に有効とされている。本実験結果の重相 関分析において、各説明変数の $\mathrm{t}$ 值はこの条件を十分に満足しており、 有効と考えられる。

重相関分析から得られた偏相関係数を用い、室温の標準偏差の予測 式を以下に示す。なお、この分析では切片の偏相関係数を 0 とした。

$$
\sigma_{t}=3.474 h_{a}+0.1978 D
$$

室温の標準偏差について実測値と予測値の関係を図10に示す。この 結果、測定値と予測值は良く一致しており、近似式としては十分実用 の範囲にあるものと考えられる。

\section{4. 室内最高温度の検証}

室内の最高温度について、(1)式から得られた計算値と実測結果を比 較し、予測方法の妥当性を検証した。12種類の全実験パターンについ て、平均室内温度上昇、最高温度上昇の実測値および計算値の時刻変 化を図 11 に示す。その結果、実験開始直後では予測值の方が実測值 よりもやや高めの温度となり、それらの差異は大きくなっているが、 時刻の経過と共にその差は減少しており、全ケースとも概ね良く再現 しているといえる。

次に、実験を行った全パターンにおいて、実測値と予測値の関係を 図 12 に示す。その結果、温度の低い領域すなわち温度上昇開始直後 の時間帯で多少差が見られる。これは、室温の標準偏差を時間の経過 に関わらず一定の値として扱っていることが原因といえる。実測值と

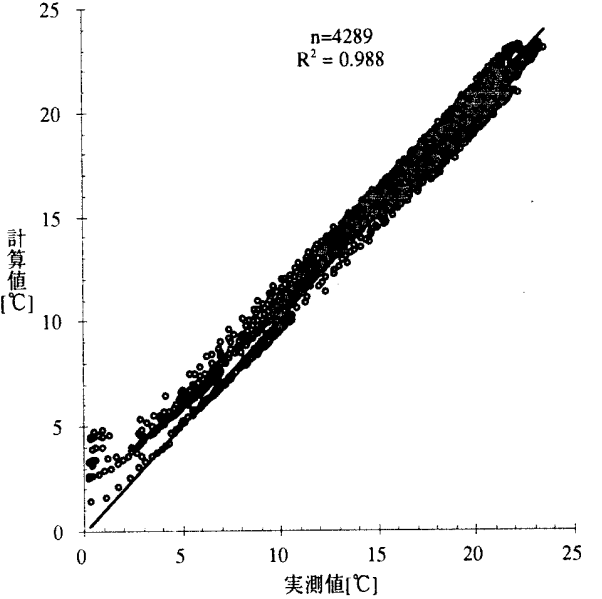

図 12 室内最高温度上昇の実測值と計算值の比較

計算値の関係を示す点群は、45 0 の直線を挟み左右に分散しており、 室温の標準偏差を求める際に生じた䛊差が、最高温度上昇の予測に影 響しているものと推察される。しかし、 $\mathrm{R}^{2}$ の值も 1 に近く、さらに熱 破壊に関わる最高温度上昇の予測は平均 $\pm 2{ }^{\circ} \mathrm{C}$ 程度の範囲に収まって いることから、室温の最高温度上昇を予測する本方法は、実用的な精 度と考えられる。

\section{5. 結論}

室内の発熱量が偏在している機械室を対象に、空調機停止後の室温 上昇を想定した実験を行い、以下の知見が得られた。 
1) 実大規模の実験から、室内に高発熱の機器を設置する場合、室内の 発熱量が偏在すると、垂直方向および水平方向の室内温度は大きな ばらつきを生ずることが確かめられた。したがって、動作温度の範 冊が規定されている機器を設置する場合、平均室温のみで設置の可 否を判断することは困難であり、室温のばらつきにも配慮して設置 する必要がある。

2) 平均室温の上昇は、室内の発熱量に偏在があっても、発熱量が同じ であれば同様の傾向を示し、その差は少ない。一方、室温の標準偏 差は、同じ発熱量であってもその偏在の程度により大きく異なって くる。室内温度の頻度分布は概ね正規分布となり、その最大温度は 平均および標準偏差を用いて精度良く推定することができる。

3) 平均室温の上昇は時刻の経過と共に徐々に上昇し、定常になるまで 長時間を要するのに対し、室温の標準偏差は室温上昇の開始後、比 較的短時間で一定となる。

4) 室温の標準偏差を決定する各種要因を設定し、相互の相関係数およ び $\mathrm{t}$ 值から説明変数として、平均発熱密度およびマハラビノスの汎 距離（室中心一発熱重心間の距離）を抽出した。さらに、重回帰分 析により、説明変数の妥当性を検証すると共に、室温の標準偏差を 推定する予測式を求めた。

5) 室温の標準偏差を求める予測式を用い、室内最高温度を推定した結 果、実測結果と良く一致し、最高温度の予測式として有効なことを 確認した。
謝辞

本研究では、NTT建築総合研究所の中里秀明氏、東京理科大学倉渕 研究室の学生諸氏の協力を得て実験を行った。ここに記して感謝の意 を表します。

\section{本研究に関連した既発表文献}

a) 木下学, 羽山広文, 石川敬康, 倉㴊隆:架調機停止後の室内温度上昇に関する研 究（その 1), 空気調和・衛生工学会学術講演論文集,pp.1089-1092,1998.8

b) 羽山広文,木下学,石川敬康,含激隆:空調機停止後の室内温度上昇に関する研 究（その２）, 空気調和・衛生工学会学術講演論文集,pp.1093-1096,1998.8

c) 石川敬康, 木下学, 羽山広文, 倉㣜隆:空調機停止後の室内温度上昇に関する研 究（その3），空気調和・衛生工学会学術講演論文集,pp.1097-1100,1998.8

\section{参考文献}

1) S.Murakami, S.Kato, T.Tanaka, D.-H.Choi, T.Kitazawa, The Influence of Supply and Exhaust Openings on Ventilation Efficiency in an Air-conditioned Room with a Raised Floor, ASHRAE Transactions , Vol. 98, pp.738-755, 1992

2) 村上周三,加藤信介: 新たな換気効率指標と三次元乱流数値シミュレーション による算出法, 空気調和・衛生工学会論文集, No.32, pp.91-102, 1986.10

3）小島昌一, 渡辺俊行, 龍有二, 赤司泰義, 西山紀光:オフィスビル空調におけ る室内混合損失の影響, 日本建築学会計画系論文集, NO.473, P.25-34, 1995.7

4) 小島昌一, 渡辺俊行, 龍有二, 赤司泰義, 西山紀光, 高橋淳一:室内空気温度分 布を考虑した室モデルによる室内混合損失シミュレーション, 日本建築学会 計画系論文集, NO.509, P.33-39, 1998.7

5) 羽山広文, 大島一夫, 高草木明, 松島修: 空調機停止後の室温変化を考慮した 空調設備の信頼性評価に関する研究, 日本建築学会計画系論文集, No.507, pp.71-78, 1998.5

6) 菅民郎：多变量統計分析, 現代数学社 